\title{
MECHANISMS CONTROLLING SURFACE WATER QUALITY IN THE COBRAS RIVER SUB-BASIN, NORTHEASTERN BRAZIL ${ }^{1}$
}

\author{
ALEXANDRE DE OLIVEIRA LIMA ${ }^{2}$, FRANCISCO PINHEIRO LIMA-FILHO $^{3}$, NILDO DA SILVA DIAS $^{4 *}$, \\ PRISCILA REGINA DO ARAGÃO REGO ${ }^{5}$, FLÁVIO FAVARO BLANCO ${ }^{6}$, MIGUEL FERREIRA NETO $^{4}$
}

\begin{abstract}
Stream water quality is dependent on many factors, including the source and quantity of the streamflow and the types of geology and soil along the path of the stream. This study aims to evaluate the origin and the mechanisms controlling the input of ions that effect surface water quality in the sub-basin of the Rio das Cobras, Rio Grande do Norte state, Northeastern Brazil. Thirteen ponds were identified for study: three in the main river and ten in the tributaries between, thus covering the whole area and lithology of the sub-basin. The samples were collected at two different times (late dry and rainy periods) in the hydrological years 2009 and 2010, equating to total of four collection times. We analyzed the spatial and seasonal behavior of water quality in the sub-basin, using Piper diagrams, and analyzed the source of the ions using Guibbs diagram and molar ratios. With respect to ions, we found that water predominate in $82 \%$ sodium and $76 \%$ bicarbonate water (cations and anions, respectively). The main salinity control mechanism was related to the interaction of the colloidal particles (minerals and organic sediment) with the ions dissolved in water. Based on the analysis of nitrates and nitrites there was no evidence of contamination from anthropogenic sources.
\end{abstract}

Keywords: Desertification. Semiarid. Salinity.

\section{MECANISMOS CONTROLADORES DA QUALIDADE DAS ÁGUAS SUPERFICIAIS NA SUB- BACIA HIDROGRÁFICA DO RIO DAS COBRAS DO NORDESTE BRASILEIRO}

\begin{abstract}
RESUMO - A qualidade da água de um rio dependente de vários fatores, incluindo a origem e quantidade de escoamento e a formação geologia dos solos ao longo do fluxo. Objetivou-se avaliar a origem e os mecanismos controladores da entrada dos íons e, consequentemente, da qualidade da água na sub-bacia do rio das Cobras, RN. Foram selecionados 13 açudes, sendo 3 no rio principal e 10 entre os afluentes, abrangendo toda a área e litologias da sub-bacia. As amostras foram coletadas em duas épocas distintas (final dos períodos secos e chuvosos) nos anos hidrológicos de 2009 e 2010, totalizando 4 momentos de coleta. Analisou-se o comportamento espacial e sazonal da qualidade da água na sub-bacia utilizando o diagrama de Piper e a origem dos íons pelo diagrama de Gibbs e razão molar. Constatou-se que em relação aos íons, predominam águas sódicas em $82 \%$ e águas bicarbonatadas 76\% (cátions e ânions), respectivamente. Os resultados obtidos sugerem que o principal mecanismo controlador da salindiade está relacionado a interação das partículas coloidais (sedimentos orgânicos e minerais) com os íons dissolvidos na água. Também não se observou indícios de contaminação antrópica na área, tendo por base a análise de nitratos e nitritos.
\end{abstract}

Palavras-chave: Desertificação. Semiárido. Salinidade.

\footnotetext{
*Corresponding author

${ }^{1}$ Received for publication in $07 / 31 / 2014$; accepted in $07 / 18 / 2016$.

Extracted from the first author's doctoral's thesis.

${ }^{2}$ Empresa de Assistência Técnica e Extensão Rural, Natal, RN, Brazil; alexandrelimarn@gmail.com.

${ }^{3}$ Department of Geology, Universidade Federal do Rio Grande do Norte, Natal, RN, Brazil; pinheiro@geologia.ufrn.br.

${ }^{4}$ Department of Environmental Sciences and Technological, Universidade Federal Rural do Semi-Árido, Mossoró, RN, Brazil; nildo@ufersa.edu.br, miguel@ufersa.edu.br.

${ }^{5}$ Instituto Nacional de Colonização e Reforma Agrária, Natal, RN, Brazil; priscila.aragao@ntl.incra.gov.br.

${ }^{6}$ Empresa Brasileira de Pesquisa Agropecuária, Embrapa Meio-Norte, Teresina, PI, Brazil; flavio.blanco@embrapa.br.
} 


\section{INTRODUCTION}

The Cobras River sub-basin, Rio Grande do Norte (RN), is located in the Seridó desertification region, and is one of the worst affected desertification areas among the various sub-basins that comprise the Piranhas-Açu basin (RN and Paraíba States) in the northeastern region of the RN. This sub-basin was chosen as a pilot area to test the effectiveness of the actions detailed in the National Plan of Action and Combat to the Desertification (PAN-LCD) drawn up by the Brazilian Government in 2004.

Currently, in state of $\mathrm{RN}$ these actions are being implemented via the construction of hydro-environmental works aiming to improve the availability of water for the rural population. However, this work is being carried out without any prior technical study that may assist the choice of the sites and indicate which preventive measures can be taken to prevent the process of salinization.

Studies considering the geochemical evolution of surface water in existing reservoirs are important tools for planning and sustainability in semiarid zone (JALALI, 2007), and provide valuable information on the behavior and seasonal, temporal and spatial variability of ionic compounds dissolved in the water within the river basins and sub-basins, as well as its dynamics in rock-soil-water systems.

Several studies have evaluated the behavior and temporal and spatial variation of ionic water quality in surface reservoirs, especially in arid and semi-arid areas where there is usually a high water deficit (XU et al., 2012; HAYNES et al., 2007; BOWMER, 2011).

The hydrochemistry of surface water is influenced by many factors, such as precipitation, geological context, and anthropogenic action by the inclusion of organic materials (YADANA, 2009) and pollution with chemicals (pesticides and herbicides) used in agriculture. In the case of semi-arid regions, the climate influence is strongly determined by the high evaporation rates and large climate variability over short distances.

Understanding the dynamics between geology, climate and human action is key for determining the mechanisms that will influence decisions regarding proper water resources management at the local level and meeting the demand of diffuse Brazilian semi-arid rural populations. The objective of this paper is to assess the origin and controlling mechanisms of ion input and the surface water quality from the Cobras River sub-basin, in the Seridó desertification region, RN.

\section{MATERIAL AND METHODS}

\section{Study area}

This work was conducted in the Cobras River sub-basin, RN, which is an integral part of the Piranhas-Açu watershed, occupying an area of $159.13 \mathrm{~km}^{2}$ (Figure 1) and belonging to the cities of Parelhas, Carnaúba dos Dantas and Jardim do Seridó (BRAZIL, 2004).

The rainy period extends from January to May, with an average annual precipitation of $612.4 \mathrm{~mm}$, average, minimum and maximum temperatures of $26.1,21.2$ and $32.0{ }^{\circ} \mathrm{C}$, respectively and, potential evapotranspiration of $1552 \mathrm{~mm}$ per year (KÖPPEN, 1948).

This water system, associated with other climatological parameters, provides the region with a drainage network consisting of intermittent rivers where the flow of surface water exists for only a few days within the rainy period. Dams are the most common method of water storage.

The sub-basin is formed by the metamorphic rocks of the crystalline basement of the Seridó, located in the far northeast of the Borborema Province. The Seridó formation occupies the largest portion of the sub-basin, covering an area of $127.81 \mathrm{~km}^{2}$ (Figure 2), representing $80.9 \%$ of the total area according to geological maps (JARDIM DE SÁ, 1998).

\section{Area and collection of samples}

The thirteen sampling points selected for hydrochemistry characterization were located in dams along the sub-basin, with three sampling points along the main river and ten in the tributaries (Figure 2), in order to cover all the lithologies within the study area.

The samples were collected both at the end of the dry periods (December 2009 and 2010) and during rainy days (August 2009 and 2010) of each hydrologic period, thus totaling four sampling times. Some dams dried up at the end of the 2010 rainy season and so it was not possible to sample all points. Fifty analyses were performed in total (Table 1).

The sampling of dams covered the largest part of the area and included all the lithologies of the sub-basin (Table 1). Analysis of Electric Conductivity (EC), Sodium Adsorption Ration (SAR), Total Dissolved Solid (TDS), hardness, $\mathrm{NO}^{3-}, \quad \mathrm{NO}_{2}{ }^{2-}, \quad \mathrm{Ca}^{+2}, \quad \mathrm{Mg}^{+2}, \quad \mathrm{Na}^{+}, \quad \mathrm{K}^{+}, \quad \mathrm{Cl}^{-}$, $\mathrm{HCO}_{3}^{-}, \mathrm{SO}_{4}^{-}, \mathrm{NH}_{4}^{+}$were performed via the methods recommended by Embrapa (1999). 

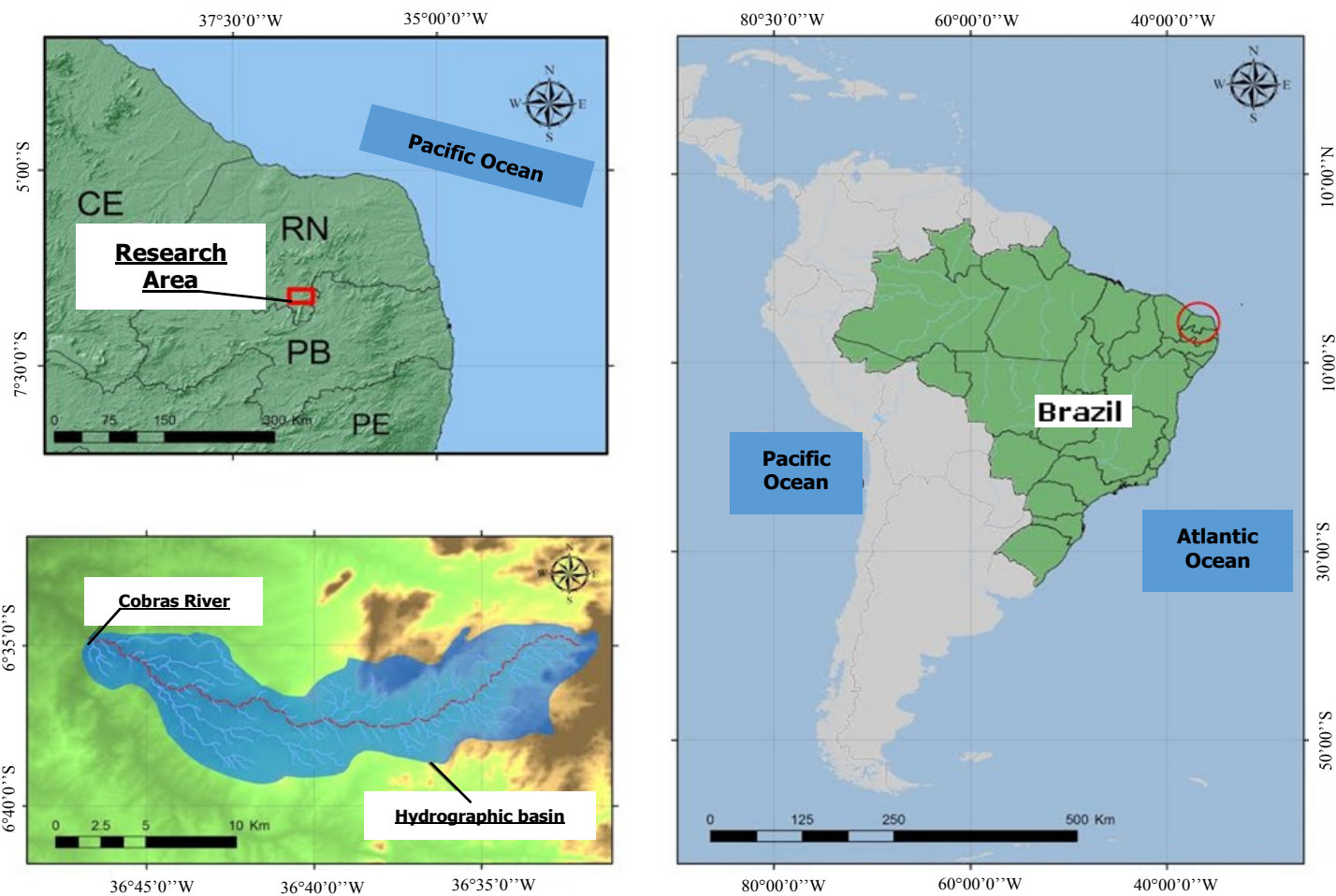

Figure 1. Coverage area in the Cobras River sub-basin, RN State, northeastern Brazil.

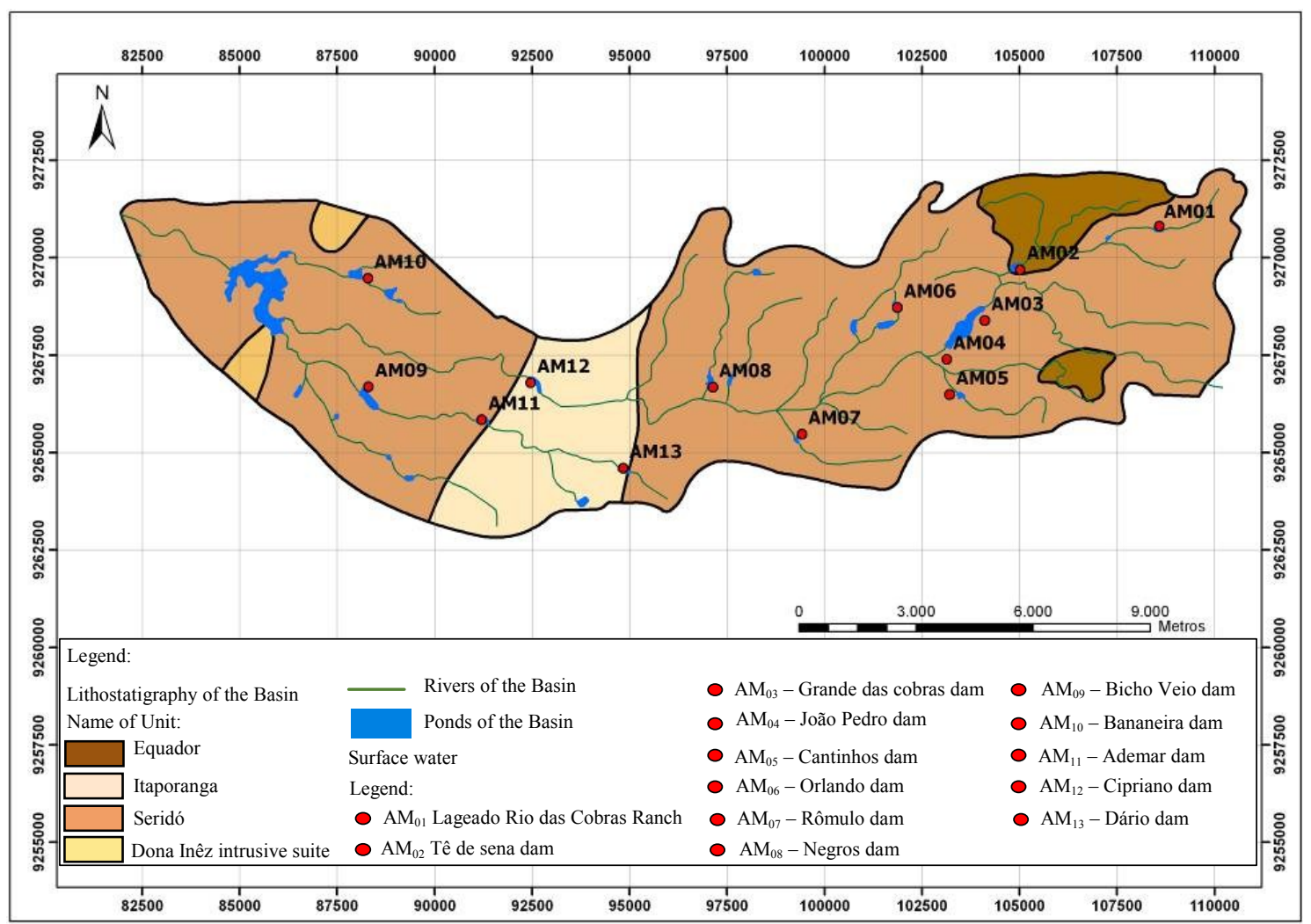

Figure 2. Location of water collection and service area of the existing lithology along the Cobras River sub-basin, RN State, northeastern Brazil.

Evaluation of quality and control mechanisms of water

The water quality was accessed with a Piper diagram using the software Qualigraf Water. The quality is classified within the triangular diagram by comparing the different water groups according to the dominant cations and anions (BARROSO et al., 2011; RAVIKUMAR et al., 2011). 
The Gibbs diagram (GIBBS, 1970) was used for understanding the control mechanisms of major ion entry to the water system. The relationship between the ionic composition of the water (hydrochemistry) and the characteristics of the predominant lithology in the region was established, taking into consideration the precipitation and evaporation.

The molar ratio between of the dissolved ions was used to identify the source of the leachate material. Therefore, distinction of aquifers was made according to their chemical composition, major cations and anions analysis and comparisons of relationships between these factors. The molar ratio was calculated from sampled period averages, totaling four average values throughout the two-year study period.

The software Qualigraf was used to perform the classification of samples using the Piper diagram to compare and classify water variability in relation to the dominantions.

Table 1. Location and water collection period sampling points along the Cobras River sub-basin, RN State, northeastern Brazil.

\begin{tabular}{|c|c|c|c|}
\hline \multicolumn{4}{|c|}{ Sampling time: year 2009} \\
\hline \multicolumn{2}{|c|}{ End of the wet season } & \multicolumn{2}{|c|}{ End of dry season } \\
\hline Sample & Location (Dam's name) & Sample & Location (Dam's name) \\
\hline 1 & Lajedo & 14 & Lajedo \\
\hline 2 & Tê de Sena & 15 & Tê de Sena \\
\hline 3 & Cobras & 16 & Cobras \\
\hline 4 & João de Pedro & 17 & João de Pedro \\
\hline 5 & Cantinhos & 18 & Cantinhos \\
\hline 6 & Orlando & 19 & Orlando \\
\hline 7 & Rômulo & 20 & Rômulo \\
\hline 8 & Negros & 21 & Negros \\
\hline 9 & Dario & 22 & Dario \\
\hline 10 & Cipriano & 23 & Cipriano \\
\hline 11 & Ademar & 24 & Ademar \\
\hline 12 & Bicho veio & 25 & Bicho veio \\
\hline \multirow[t]{2}{*}{13} & Bananeiras & 26 & Bananeiras \\
\hline & & Ir 2010 & \\
\hline \multicolumn{2}{|c|}{ End of the wet season } & \multicolumn{2}{|c|}{ End of dry season } \\
\hline Sample & Location (Dam's name) & Sample & Location (Dam's name) \\
\hline 27 & Lajedo & 40 & Lajedo \\
\hline 28 & Tê de Sena & 41 & Tê de Sena \\
\hline 29 & Cobras & 42 & Cobras \\
\hline 30 & João de Pedro & 43 & João de Pedro \\
\hline 31 & Cantinhos & 44 & Cantinhos \\
\hline 32 & Orlando & 45 & Orlando \\
\hline 33 & Rômulo & 46 & Rômulo \\
\hline 34 & Negros & 47 & Negros \\
\hline 35 & Dario & 48 & Dario \\
\hline 36 & Cipriano & 49 & Cipriano \\
\hline 37 & Ademar & 50 & Ademar \\
\hline 38 & Bicho veio & 51 & Bicho veio \\
\hline 39 & Bananeiras & 52 & Bananeiras \\
\hline
\end{tabular}

\section{RESULTS AND DISCUSSION}

\section{Hydrochemistry assessment}

Increasing values of hardness, TDS and EC were observed between the first 2009 sampling, at the end of the rainy season, and the fourth collection at the end of the 2010 dry season (Table 2). This is probably due to a reduction of rain in the dry season when evaporation increases the salt concentrations in the water. Despite the low levels of salinity at some sampling points, for example, the first collection in $2009\left(\mathrm{EC}=0.1 \mathrm{dS} \mathrm{m}^{-1}\right)$, this water presents some salinization potential for irrigated areas if management practices for keeping the EC in the root zone close to the threshold EC of crops are not adopted (PORTO FILHO et al., 2011). The EC results of collected water samples indicated that the sources had a low risk of salinity and sodicity for use in irrigation (Table 2).

The levels of bicarbonate in the water directly influenced the water $\mathrm{pH}$ in both years (Table 2). Minimum, maximum and average values of water $\mathrm{pH}$ were $7.5,8.8$ and 7.0 , respectively, which are within the range of normality for irrigation purposes; thus, waters can be used for irrigation without restriction with regard to nutritional imbalance risks to crops (AYERS; WESTCOT, 1999).

Maximum nitrate $\left(4.54 \mathrm{mg} \mathrm{L}^{-1}\right)$ and nitrite $\left(1.0 \mathrm{mg} \mathrm{\textrm {L } ^ { - 1 }}\right.$ ) concentrations were within the acceptable value ranges. Nitrate is a major contaminant of groundwater and surface water, thus there was no evidence of anthropogenic contamination. 
Table 2. Maximum, medium and minimum values of quality in collected water samples in the years of 2009 and 2010 hydrological in Cobras River sub-basin, RN State, northeastern Brazil.

\begin{tabular}{|c|c|c|c|c|c|c|c|c|c|c|c|c|}
\hline \multirow{2}{*}{ Parameters } & \multicolumn{3}{|c|}{$\begin{array}{l}1 \text { collection } \\
\text { (final rain-2009) }\end{array}$} & \multicolumn{3}{|c|}{$\begin{array}{l}2 \text { collection } \\
\text { (dry end-2009) }\end{array}$} & \multicolumn{3}{|c|}{$\begin{array}{l}3 \text { collection } \\
\quad \text { (final rain-2010) }\end{array}$} & \multicolumn{3}{|c|}{$\begin{array}{c}4 \text { collection } \\
\text { (dry end-2010) }\end{array}$} \\
\hline & Max. & Min. & Average & Max. & Min. & Average & Max. & Min. & Average & Max. & Min. & Average \\
\hline $\mathrm{EC}\left(\mathrm{dS} \mathrm{m} \mathrm{m}^{-1}\right)$ & 0.55 & 0.10 & 0.23 & 1.00 & 0.15 & 0.42 & 1.88 & 0.16 & 0.65 & 2.42 & 0.22 & 0.76 \\
\hline $\operatorname{TDS}\left(\mathrm{mg} \mathrm{L}^{-1}\right)$ & 364.00 & 38.80 & 138.23 & 557.20 & 85.20 & 238.49 & $1,180.00$ & 92.00 & 405.32 & $1,694.00$ & 126.80 & 491.58 \\
\hline Nitrite $\left(\mathrm{mg} \mathrm{L}^{-1}\right)$ & 0.46 & 0 & 0.084 & 1.00 & 0 & 0.134 & 0.52 & 0 & 0.097 & 0.45 & 0 & 0.13 \\
\hline Nitrate $\left(\mathrm{mg} \mathrm{L}^{-1}\right)$ & 0 & 0 & 0 & 4.54 & 0 & 1.20 & 1.55 & 0 & 0.532 & 1.04 & 0 & 0.36 \\
\hline $\mathrm{Ca}^{++}\left(\mathrm{mg} \mathrm{L}^{-1}\right)$ & 19.73 & 0 & 10.34 & 66.06 & 10.42 & 23.05 & 40.07 & 3.63 & 19.12 & 33.78 & 3.09 & 18.54 \\
\hline $\mathrm{Mg}^{++}\left(\mathrm{mg} \mathrm{L}^{-1}\right)$ & 17.18 & 4.26 & 8.63 & 17.51 & 3.33 & 10.79 & 47.45 & 5.09 & 20.04 & 93.17 & 5.39 & 24.67 \\
\hline $\mathrm{CO}_{3}^{-}\left(\mathrm{mg} \mathrm{L}^{-1}\right)$ & 0.39 & 0 & 0.052 & 7.72 & 0 & 1.45 & 30.52 & 0 & 4.36 & 10.85 & 0 & 2.24 \\
\hline $\mathrm{HCO}_{2}^{-}\left(\mathrm{mg} \mathrm{L}^{-1}\right)$ & 145.76 & 46.94 & 88.03 & 314.03 & 68.04 & 155.18 & 486.61 & 64.77 & 193.21 & 541.00 & 9.80 & 182.50 \\
\hline $\begin{array}{c}\mathrm{SO}_{4}^{-}\left(\mathrm{mg} \mathrm{L}^{-1}\right) \\
\mathrm{Cl}^{-}\left(\mathrm{mg} \mathrm{L}^{-1}\right)\end{array}$ & $\begin{array}{r}5.91 \\
101.06 \\
\end{array}$ & $\begin{array}{l}0 \\
9.94\end{array}$ & $\begin{array}{r}2.73 \\
35.56 \\
\end{array}$ & $\begin{array}{r}6.86 \\
178.06\end{array}$ & $\begin{array}{c}0 \\
14.54 \\
\end{array}$ & $\begin{array}{r}3.10 \\
63.00\end{array}$ & $\begin{array}{r}24.02 \\
468.08\end{array}$ & $\begin{array}{r}0.78 \\
15.17 \\
\end{array}$ & $\begin{array}{r}6.50 \\
133.38 \\
\end{array}$ & $\begin{array}{r}11.95 \\
656.27 \\
\end{array}$ & $\begin{array}{c}0.66 \\
20.86\end{array}$ & $\begin{array}{r}4.74 \\
155.87 \\
\end{array}$ \\
\hline
\end{tabular}

As previously mentioned in Table 2, a study of chloride concentrations in the Cobras River subbasin indicated that chloride concentrations exceeding $650 \mathrm{mg} \mathrm{L}^{-1}$ contributed to increased EC $\left(2.42 \mathrm{dS} \mathrm{m}^{-1}\right)$ in the sub-basin during end of the 2010 dry season (four samples). Many of the resultant concentrations of chloride in the sub-basin studied were 100 to $650 \mathrm{mg} \mathrm{L}^{-1}$, which is above the standard for chloride $\left(100 \mathrm{mg} \mathrm{L}^{-1}\right)$ for class one streams.
Precipitation reached $841 \mathrm{~mm}(27 \%$ above average) in 2009 and $733 \mathrm{~mm} \mathrm{(16.4 \%} \mathrm{above}$ average) in 2010 (Figure 3), which probably influenced the EC. The TDS and EC in streams are usually higher during low flow periods than during high flow periods. The semiarid zone is characterized as a region of high temperatures and high temporal and spatial rainfall variability; therefore, water shortage is the major limiting factor in agricultural production (BARROSO et al., 2010).

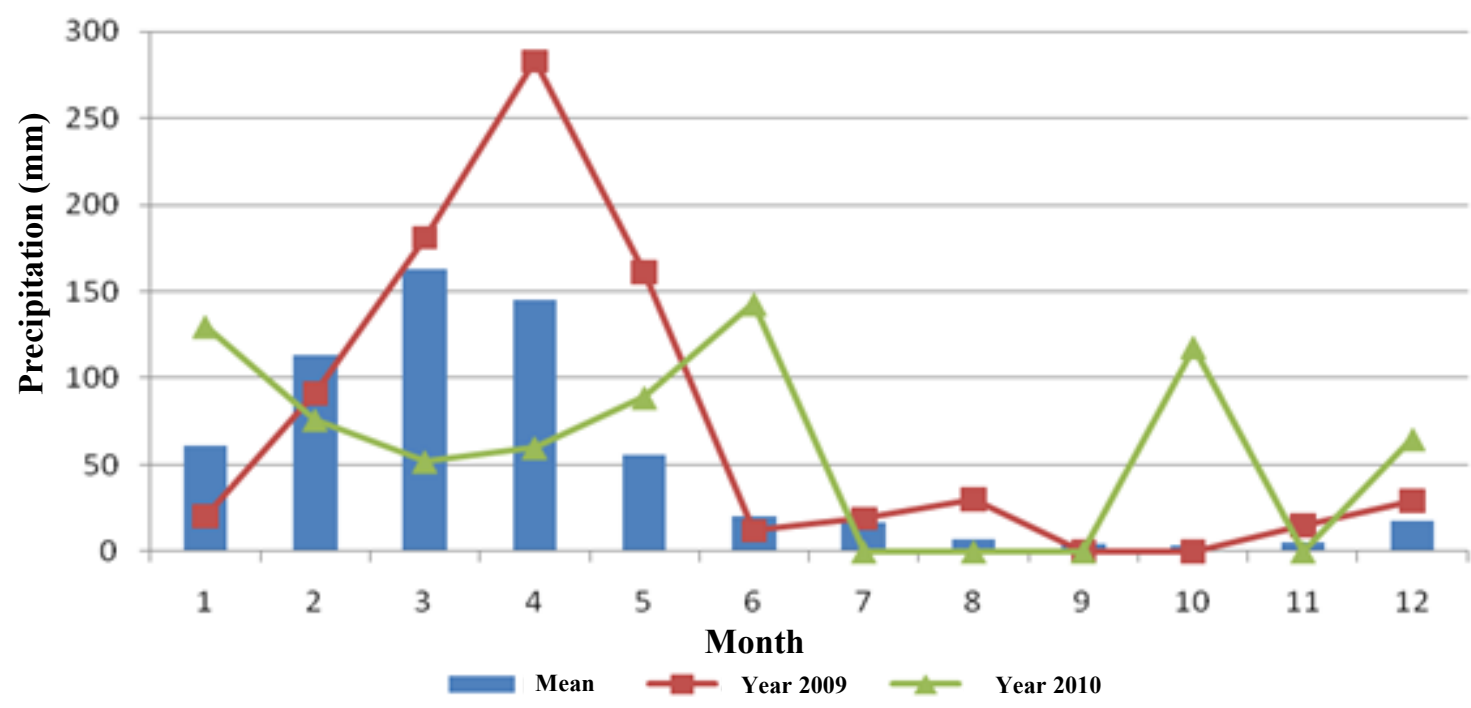

Figure 3. Precipitation observed in the area of the Sub-basin of the Cobras river in 2009 and 2010.

Evaluation of water hydrochemistry and molar ratios

A predominance of sodic waters in an 82 and $18 \%$ mix was observed (Figure 4). For anions, bicarbonate was predominant at $76 \%$, chloride at
$14 \%$ and mixed anions at $10 \%$ in the samples. The joint analysis of cations and anions indicated the predominance of sodium-bicarbonate in waters at $58 \%$, followed by sulphated or sodium-chloride water at $24 \%$ and bicarbonated-calcium or magnesium at $12 \%$. 
This behavior shows that the water hydrochemistry responses are related to the precipitates, since in 2010 the rains were smaller and irregularly distributed throughout the year, when compared to the year 2009 (Figure 3).

\section{Larger cations}

$\mathrm{Na}^{+}$was dominant cation in the four samplings. The predominance of cations in samples were: 1st) $\mathrm{Na}^{+}>\mathrm{K}^{+}>\mathrm{Mg}^{++}>\mathrm{Ca}^{++} ; 2$ nd) $\mathrm{Na}^{+}>\mathrm{Ca}^{++}$ $>\mathrm{K}^{+}>\mathrm{Mg}^{++}$; 3rd) $\mathrm{Na}^{+}>\mathrm{Mg}^{++}>\mathrm{Ca}^{++}>\mathrm{K}^{+}$and 4th) $\mathrm{Na}^{+}>\mathrm{Mg}^{++}>\mathrm{Ca}^{++}>\mathrm{K}^{+}$.

Molar ratio $\mathrm{rNa} / \mathrm{rCl}$ was always $<1$ (Figure $5 \mathrm{~A}$ ) and there was an increase in this relationship between the end of the rain in 2009 and the end of the dry period of the same year. At the end of the rainy season of 2010 there was a sharp decrease $\mathrm{rNa} /$ $\mathrm{rCl}$ because of the increased quantities of $\mathrm{Cl}^{-}$ dissolved in the water.

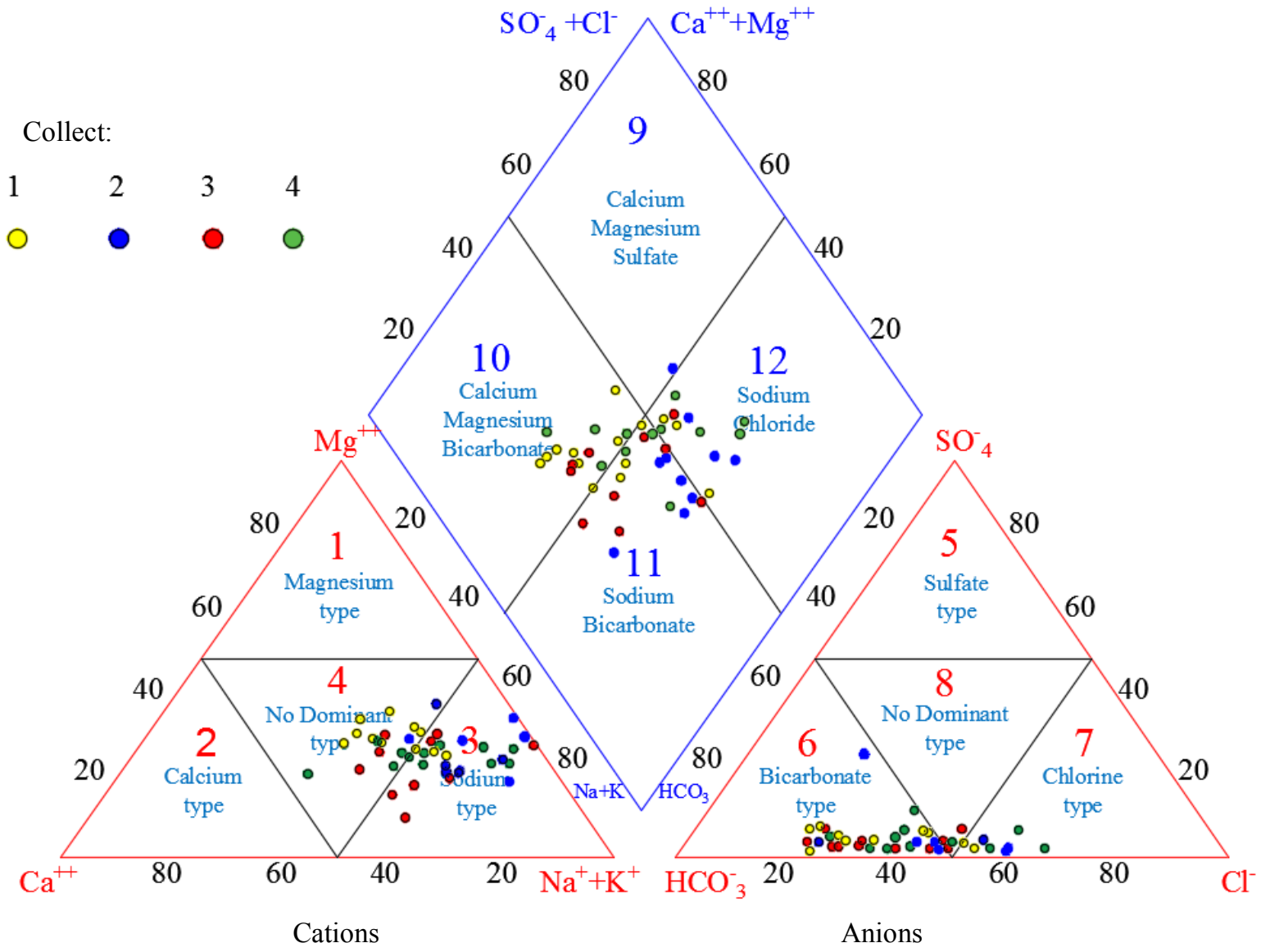

Figure 4. Piper diagram for surface water samples along the Cobras River sub-basin, RN.

Calcium occupies intermediate positions, even with significant losses of this cation in relation to original rock (also observed for $\mathrm{Na}^{+}$) due to its adsorption by colloidal particles (clays and organic matter) and becoming part of a complex, thus reducing its presence as a dissolved cation in the water (PEREIRA et al., 2006).

This trend can be observed in the relationship between $\mathrm{rNa} / \mathrm{rCa}$ molar (Figure $5 \mathrm{~B}$ ), where it is clear that between the first sampling in 2009 and the last in 2010, a gradual growth occurred in the relationship, with a consequent increase in the EC.

The $\mathrm{K}^{+}$had a prominent position in the first sampling at the end of the 2009 rainy season when rainfall and runoff were higher. After that, there was a progressive decrease in $\mathrm{K}^{+}$dissolved in water.

\section{Larger Anions}

Bicarbonate was the larger anion (Table 2), showing $\mathrm{HCO}_{3}^{-}>\mathrm{Cl}^{-}>\mathrm{SO}_{4}^{-2}>\mathrm{CO}_{3}^{-2}$ in the four samplings. There was a gradual decrease of the relationship $\mathrm{rHCO} / \mathrm{rCl}$ over the hydrological years of 2009 and 2010 due to the increase of $\mathrm{Cl}^{-}$ concentration in water (Figure 6).

This growth can be related to lower precipitation (Figure 3) that lead to lower water levels in the reservoirs and resulted in increasing concentrations of organic matter and increasing EC between 2009 and 2010 (Table 2). 

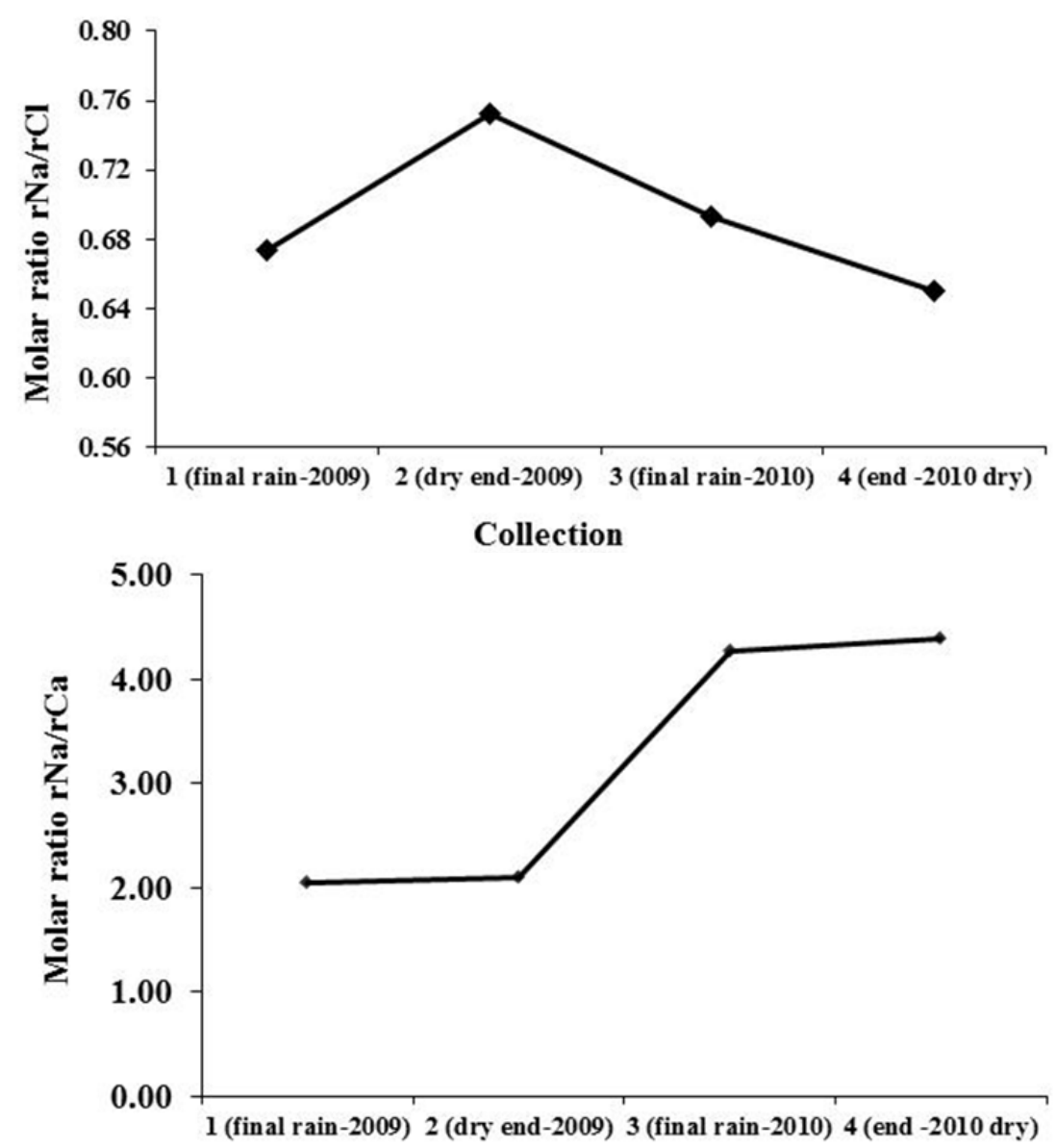

\section{Collection}

Figure 5. Variation of the molar ratios $\mathrm{rNa} / \mathrm{rCl}$ (A) and $\mathrm{rNa} / \mathrm{rCa}(\mathrm{B})$ into the dry and rainy seasons of 2009 and 2010 in Cobras River Sub-basin, RN.

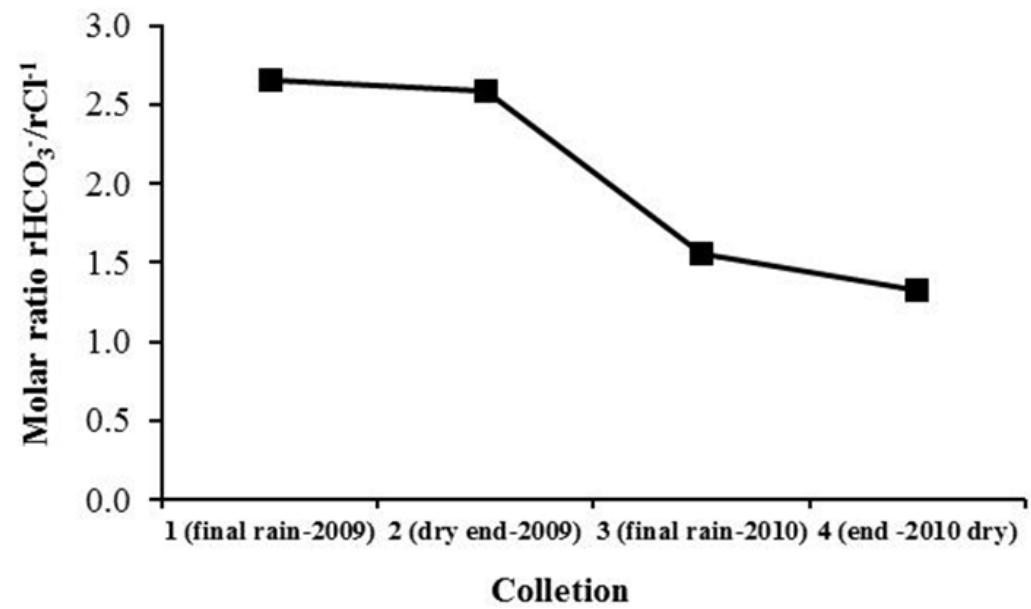

Figure 6. Variation of the molar ratio $\mathrm{rHCO}_{3}{ }^{-} / \mathrm{rCl}^{-1}$ in the dry and rainy seasons of the years of 2009 and 2010 hydrological in Cobras River Sub-basin, RN.

There are three main mechanisms of inclusion of $\mathrm{Cl}^{-}$ions in water: atmospheric contribution through rain, rock weathering of silicate minerals and rocks, and anthropogenic pollution (SINGH et al., 2004; JALALI, 2007; AL-SHAIBANI, 2008).

The owners of these reservoirs routinely plant grass for supplying cattle fodder and this contributes to the large accumulation of organic matter, which enhances these locations as $\mathrm{Cl}^{-}$sources to the system. This fact was corroborated by Helena et al. (2000) who also found no geological explanation for the presence of $\mathrm{Cl}^{-}$in the water of the River Pisuerga, Spain; instead, they justified the results by contamination by sewage and waste deposits (organic matter).

As mentioned earlier, in the case of the 
Cobras River Sub-basin/RN, it is possible to suggest that the two possible mechanisms for the inclusion of $\mathrm{Cl}^{-}$must is related to rock weathering of biotite and via the release of $\mathrm{Cl}^{-}$via vegetable decomposition (primary source). As this sub-basin is $170 \mathrm{~km}$ from the sea (which is a main source of chlorine via precipitation), the inclusion mechanism via precipitation should contribute to a lesser degree since there is an exponential decrease in precipitation $\mathrm{Cl}^{-}$content with distance from the coast.

The origin of $\mathrm{HCO}_{3}{ }^{-}$is related to the presence of $\mathrm{CO}_{2}$ dissolved in rainwater: $\mathrm{CO}_{2}+\mathrm{H}_{2} \mathrm{O}=\mathrm{HCO}_{3}^{-}+\mathrm{H}^{+}$. Depending on the closeness and contact with the atmosphere there is a tendency for the superficial reservoirs to have a large $\mathrm{HCO}_{3}{ }^{-}$content, when compared to confined aquifers .

Other sources of this anion are organic degradation and rock weathering of silicates. Thus, the prevalence of $\mathrm{HCO}_{3}{ }^{-}$in surface water points to the aforementioned sources (organic degradation and interaction with the atmosphere).

\section{Control mechanisms of water quality}

From the information above, $\mathrm{Na}^{+}, \mathrm{HCO}_{3}{ }^{-}$and $\mathrm{Cl}^{-}$ions dominate in water samples collected in the Cobras River sub-basin, RN, regardless of season (rain or dry). Furthermore, the $\mathrm{Na}^{+}$and the $\mathrm{Cl}^{-}$have a strong influence on the EC of the sub-basin water. Due to this dominance, it is appropriate to assess the origin of these ions within the study area, in addition to the processes related to their entry into the system.

A diagram that is widely used to understand the sources of hydro chemical controllers and the chemical composition of the water, is the model proposed by Gibbs (1970). According to the results obtained from the use of this diagram (Figure 7), it is observed that the origin of the ions is most strongly related with the local geology.

However, as the contact-time of dam surface water with the geology is short when compared with the confined aquifers groundwater (YADANA, 2009), we can say that the influence of lithology settles through the colloidal particles of mineral origin arriving to dams through runoff, with cation exchange capacity prevailing as a mechanism of control (solid-water interface).

Also by using the Gibbs diagram to understand the source of ions in the Gameleira River basin in Ceará, Pereira et al. (2006) reached the same conclusion when assigning rock-water integration as the dominant control on the ions present in the abovementioned area waters.

\section{A}
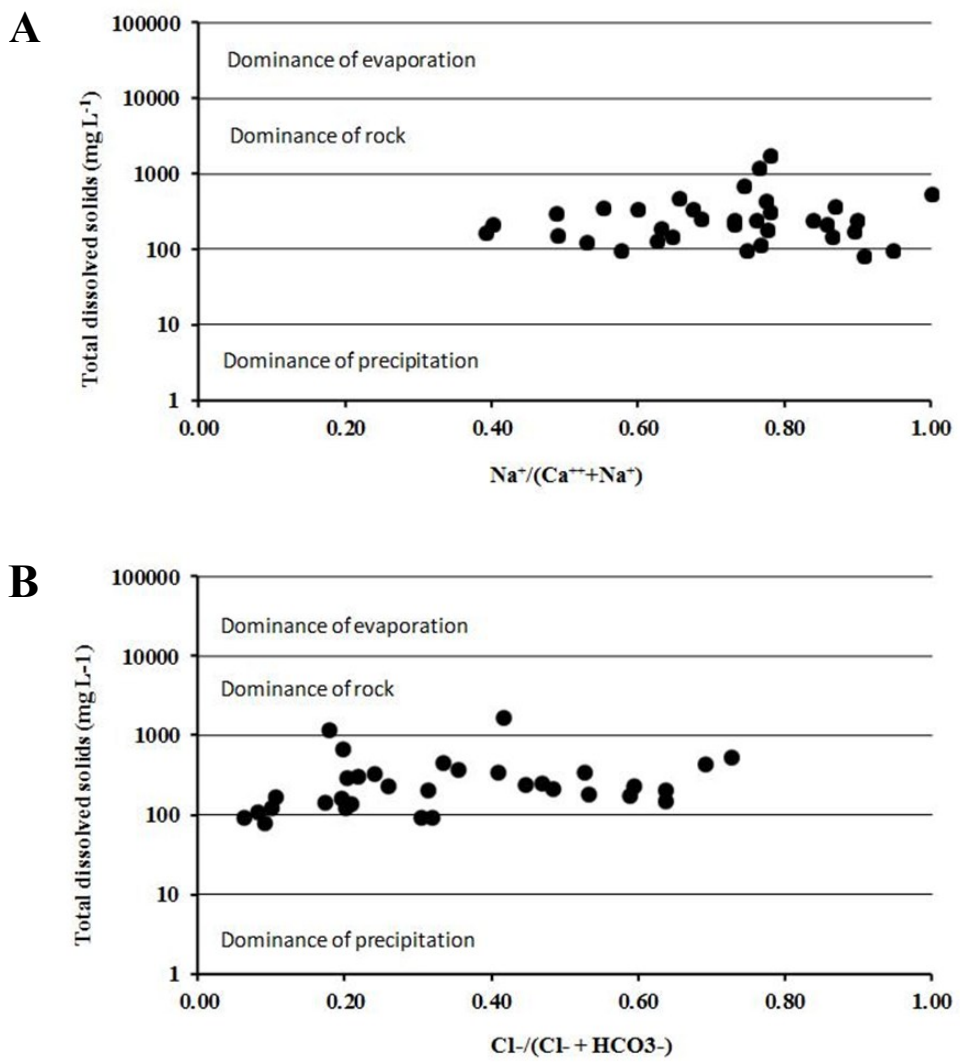

Figure 7. Gibbs diagram for control factor of water quality related to surface cations (A) and anions (B). 


\section{CONCLUSIONS}

There was no evidence of anthropogenic contamination within the Cobras River sub-basin, RN.

$\mathrm{Na}^{+}$was the dominant cation in all four samplings. For anions, $\mathrm{HCO}_{3}^{-}$was dominant and there is a trend of decreasing of $\mathrm{HCO}_{3}{ }^{-}$with the increase of $\mathrm{Cl}^{-}$and $\mathrm{EC}$ during the last sampling.

The main salinity control mechanism is related to rock-water interactions, through the interaction of colloidal particles with the ions dissolved in water (cation exchange).

\section{REFERENCES}

AL-SHAIBANI, A. M. Hydrogeology and hydrochemistry of the aquifer, shalow western Saud Arabia. Hydrogeology Journal, Berlin, v. 16, n. 1, p. $155-165,2008$.

AYERS, R. S.; WESTCOT, D.W. A qualidade da água na agricultura. 2. ed. Campina Grande, $\mathrm{PB}$ : UFPB, 1999, 153 p. (Estudos de Irrigação e Drenagem 29).

BARROSO, A. A. et al. Avaliação da qualidade da água para irrigação na região Centro Sul no Estado do Ceará. Revista Brasileira de Engenharia Agrícola e Ambiental, Campina Grande, v. 15, n. 6, p. $588-593,2011$.

BARROSO, A. de A. F. et al. Avaliação qualitativa das águas subterrâneas para irrigação na região do Baixo Jaguaribe - Ceará. Revista Brasileira de Agricultura Irrigada, Fortaleza, v. 4, n. 3, p. 150$155,2010$.

BOWMER, K. H. Water resource protection in Australia: Links between land use and river health with a focus on stubble farming systems. Journal of Hydrology, Amsterdam, v. 403, n. 1-2, p. 176-185, 2011.

BRAZIL. Programa de Ação Nacional de Combate à Desertificação e Mitigação dos Efeitos da Seca (PAN-Brasil). 1. ed. Brasília, DF: Ministério do Meio Ambiente, 2004. 112 p.

EMBRAPA. Manual de análises químicas de solos, plantas e fertilizantes. 1. ed. Rio de Janeiro, RJ: Centro nacional de Pesquisa em Solos, 1999. 370 p.

GIBBS, R. Mechanisms controlling world water chemistry. Science, Washington, v. 170, n. 3962, p. 1088-1090, 1970.
HAYNES, D. et al. Assessment of the Water Quality and Ecosystem Health of the Great Barrier Reef (Australia): Conceptual Models. Environmental Management, v. 40, p. 993-100, 2007.

HELENA, B. et al. Temporal evolution of groundwater composition in an alluvial aquifer (Pisuerga river, Spain) by principal component analysis. Water Research, Amsterdam, v. 34, n. 3, p. $807-816,2000$.

JALALI, M. Assessment of the chemical components of famenin groundwater, Western Iran. Environmental Geochemistry and Health, v. 29, n. 5, p. 357-374, 2007.

JARDIM DE SÁ, E. F. Mapa Geológico do Estado do Rio Grande do Norte. 1: 500,000. Christmas: DNPM/UFRN/PETROBRAS/CPRM, 1998.

KÖPPEN, W. Climatologia: com um estúdio de los climas de la tierra. In: Climatology. Laboratory of Climatology, New Gersey. 1948. 104 p.

PEREIRA, L. et al. A salinidade das águas superficiais e subterrâneas na bacia da Gameleira, Município de Aiuaba/CE, Revista Água Subterrâneas, São Paulo, v. 20, n. 2, p. 9-18, 2006.

PORTO FILHO, F. Q. et al. Evolução da salinidade e $\mathrm{pH}$ de solo sob cultivo de melão irrigado com água salina. Revista Brasileira de Engenharia Agrícola e Ambiental, Campina Grande, v. 15, n. 11, p. 11301137, 2011.

RAVIKUMAR, P; SOMASHEKAR, R. K.; ANGINE, M. Hydrochemistry and evaluation of groundwater Hydrochemistry and evaluation of suitability for irrigation and drinking purposes in the Markandeya river basin, Belgaum District, Karnataka State, India. Environmental Monitoring and Assessment, Berlin, v. 173, n. 1-4, p. 459-487, 2011.

SINGH, K. P. et al. Multivariate statistical techniques for the evaluation of spatial and temporal variation in water quality of River Gomti (India) - a case study. Water Research, Amsterdan, v. 38, n. 18 , p. $3980-3992,2004$.

$\mathrm{XU}, \mathrm{H}$. et al. Spatiotemporal Variation Assessment and Analysis of Water Quality in the River Zhangweinan Basin, China. Procedia Environmental Sciences, Amsterdam, v. 13, p. 1641 $-1652,2012$.

YADANA, S. M. The hydrochemical framework of surface water basins in southern Ghana. Environment Geology, Berlin, v. 57, n. 4, p. 789796, 2009. 